\title{
Epithelial Cells Transfer: An Experimental Study
}

Piters A*, Esponda A, Monique G, Doutremepuich A, Fromentin S and Doutremepuich C

Medico-Legal Hematology Laboratory, 41-43, Avenue de la Republique - CS 51636, 33073 Bordeaux Cedex, France

*Corresponding author: Piters A, Medico-Legal Hematology Laboratory, 41-43, Avenue de la Republique - CS 51636, 33073 Bordeaux Cedex, France, Tel: 0557220303; E-mail: secretariat@adn-laboratoire.com

Received date: October 26, 2017; Accepted date: November 02, 2017; Published date: November 08, 2017

Copyright: (c) 2017 Piters A, et al. This is an open-access article distributed under the terms of the Creative Commons Attribution License, which permits unrestricted use, distribution, and reproduction in any medium, provided the original author and source are credited.

\section{Abstract}

Objective: The objective of the present study was to analyze the conditions of epithelial cells transfer after an initial deposition on a first object to a second object (secondary transfer).

This study should provide an experimental model which should contribute to better understand and analyze all the transfer mechanisms.

Methods: Using glass slides and cotton gauzes as supports for the transfer of epithelial cells from an object to another one, we analyzed the occurrence and efficiency of cells transfer in different conditions of hygrometry and contact.

Results: Our investigation reveals that after one hour deposition on a glass slide, the epithelial cells are no longer able to transfer to a second support.

Moreover, our results also demonstrate that in opposition with the environmental factors such as hygrometry which are determinant for the transfer mechanisms, the strength of the contact between the glass slide and cotton gauze does not influence the cells transfer efficiency.

Conclusion: In conclusion, the secondary transfer of epithelial cells is only possible if the cells are not strongly attached to their support.

Keywords: DNA; Epithelial cells; Cells transfer; PCR

\section{Introduction}

Epithelial cells deposition on a weapon, bullet casing or person is routinely analyzed with a very high success rate.

During the last decade, DNA analysis from epithelial cells has become a component of fundamental importance in legal and criminal investigations.

Cells deposition on an object or person can be either due to a primary transfer, when the cells deposition occurs directly between a person and the object, or due to a secondary transfer when the cells deposition occurs between a person and an object in a first time, and then between this object and another person or object in a second time [1].

Forensic laboratories can detect and analyze DNA but they are still unable to distinguish between primary and secondary cells deposition mechanisms.

However, this precise question represents a very crucial and critical point during the expert deposition at the court.

Research projects and experiments have been conducted to address the question of these transfer mechanisms but unfortunately, the major defect in these studies relies on their non-reproducibility [1].
Therefore, our laboratory developed a specific experimental model to study the cells transfer mechanisms. This model is reproducible, reliable, and should allow deciphering between primary and secondary epithelial cells transfer.

Here, we present a method based on the utilization of a glass slide as support to analyze the transfer of epithelial cells in two conditions:

1. Primary transfer by deposing the cells directly on the glass slide. In this case, we observed that the cells drying rate represent an important parameter in this study.

2. Secondary transfer by applying cotton gauze on the glass slide with a constant weight for 10 seconds to allow the transfer of the cells from the glass slide to the cotton gauze.

\section{Materials and Methods}

A cell suspension was prepared using a buccal swab sample from one donor re-suspended in water. After homogenization, $1 \mu \mathrm{l}, 10 \mu \mathrm{l}$ and $100 \mu \mathrm{l}$ of the cell suspension were added to glass slides.

Then, the slides were allowed to air dry at room temperature $\left(22^{\circ} \mathrm{C}\right)$ for $0,1,3,6,9$ and 24 hours. Samples were prepared in triplicates for each condition. Corresponding control slides were prepared using the same protocol but directly used for DNA extraction, without any air drying step.

To mimic cells transfer, cotton gauzes were placed on the slide and a weight of 20 and $200 \mathrm{gm}$ applied for 10 seconds. Then, the gauzes were 
Citation: Piters A, Esponda A, Monique G, Doutremepuich A, Fromentin S, et al. (2017) Epithelial Cells Transfer: An Experimental Study. J

Page 2 of 4

used for DNA extraction. Cotton gauze without contact with the slides was used as control. DNA was extracted using the EZ1 extraction protocol (EZ1 Investigator Kit, QIagen, US) with EZ1 Advanced XL device according to manufacturer recommendations.

To determine the concentration of human DNA in each sample, the Investigator Quantiplex Kit (QIagen) has been used in conjunction with the Applied Biosystems 7500 Real Time Investigator Quantiplex Instrument.

Following DNA extraction, PCR were performed on each sample using the AmpFISTR Identifiler Plus PCR amplification Kit (Thermo Fischer Scientific). PCR products were then detected using the 3500 genetic analyzer (Applied Biosystems) [2-4].

\section{Results and Discussion}

Quantification and amplification of STR profiles in the different experimental conditions are reported in (Tables 1 and 2).
No contamination was observed on the control cotton gauze. In control conditions, without the air drying step, cells transfer from glass slides to cotton gauzes occurs in all conditions tested.

After a one hour air drying step, with $1 \mu$ l and $10 \mu$ of cell suspension on the slide, DNA concentrations do not reach the detection threshold $(\leq 3.83 \mathrm{E}-03 \mathrm{ng} / \mu \mathrm{l})$ and transfer to the cotton gauze is not possible, independently of the weight applied during the 10 second transfer step.

However, using $100 \mu \mathrm{l}$ of cell suspension and a weight of $20 \mathrm{gm}$ and $200 \mathrm{gm}$ during the transfer step, cells transfer were observed in all conditions, even after a 9 and 24 hours air drying time (Tables 1 and 2, Figures 1 and 2).

These results demonstrate that cells transfer from object A to object $B$ depends mainly on two important parameters which have to be considered: the quantity of cells transferred and the air drying time.

\begin{tabular}{|c|c|c|c|c|}
\hline $\begin{array}{l}\text { Suspension cell } \\
\text { Volume }(\mu \mathrm{l})\end{array}$ & Air dried time (hour) & DNA concentration (mean; $\mathrm{ng} / \mathrm{\mu l}$ ) & Standard deviation & DNA profiles Result \\
\hline \multirow{7}{*}{1} & 0 & $1.26 \mathrm{E}-01$ & $1.58 \mathrm{E}-02$ & Complete result \\
\hline & 1 & 3.07E-03 & $3.84 \mathrm{E}-03$ & None \\
\hline & 3 & 2.26E-04 & 3.20E-04 & None \\
\hline & 6 & $2.33 \mathrm{E}-03$ & 1.65E-03 & None \\
\hline & 9 & 4.94E-03 & $3.53 \mathrm{E}-03$ & None \\
\hline & 24 & 1.15E-03 & $5.85 \mathrm{E}-04$ & None \\
\hline & Positive control & $1.08 \mathrm{E}-01$ & & Complete result \\
\hline \multirow{7}{*}{10} & 0 & 7.36E-01 & $8.72 \mathrm{E}-02$ & Complete result \\
\hline & 1 & $3.41 \mathrm{E}-02$ & 3.83E-02 & None \\
\hline & 3 & $2.31 \mathrm{E}-03$ & $2.79 \mathrm{E}-03$ & None \\
\hline & 6 & $3.79 \mathrm{E}-03$ & $2.85 \mathrm{E}-03$ & None \\
\hline & 9 & $1.85 \mathrm{E}-03$ & $1.32 \mathrm{E}-03$ & None \\
\hline & 24 & 8.93E-04 & 1.26E-03 & None \\
\hline & Positive control & $1.28 \mathrm{E}+00$ & & Complete result \\
\hline \multirow{7}{*}{100} & 0 & $6.05 E+00$ & 3.31E-01 & Complete result \\
\hline & 1 & $4.60 \mathrm{E}+00$ & 4.37E-01 & Complete result \\
\hline & 3 & 8.84E-03 & $9.11 \mathrm{E}-03$ & Complete result \\
\hline & 6 & $1.58 \mathrm{E}-03$ & $1.12 \mathrm{E}-03$ & Complete result \\
\hline & 9 & $1.51 \mathrm{E}-03$ & $1.09 \mathrm{E}-03$ & Complete result \\
\hline & 24 & 4.13E-04 & 3.33E-04 & None \\
\hline & Positive control & $3.33 \mathrm{E}+00$ & & Complete result \\
\hline
\end{tabular}

Table 1: DNA quantification and amplification results for cells transfer with a weight of $20 \mathrm{gm}$. 
Citation: Piters A, Esponda A, Monique G, Doutremepuich A, Fromentin S, et al. (2017) Epithelial Cells Transfer: An Experimental Study. J Forensic Res 8: 397. doi:10.4172/2157-7145.1000397

Page 3 of 4

\begin{tabular}{|c|c|c|c|c|}
\hline $\begin{array}{l}\text { Suspension cell volume } \\
(\mu \mathrm{l})\end{array}$ & Air dried time (hour) & $\begin{array}{l}\text { DNA concentration (mean; } \\
\mathrm{ng} / \mathrm{\mu l} \text { ) }\end{array}$ & Standard deviation & DNA profiles result \\
\hline \multirow{7}{*}{1} & 0 & $3.46 \mathrm{E}-01$ & $1.52 \mathrm{E}-02$ & Complete result \\
\hline & 1 & $0.00 \mathrm{E}+00$ & & None \\
\hline & 3 & $1.72 \mathrm{E}-05$ & 2.43E-05 & None \\
\hline & 6 & 4.23E-05 & $5.99 \mathrm{E}-05$ & None \\
\hline & 9 & $2.24 \mathrm{E}-04$ & $1.56 \mathrm{E}-04$ & None \\
\hline & 24 & $1.11 \mathrm{E}-03$ & $1.51 \mathrm{E}-03$ & None \\
\hline & Positive control & $3.80 \mathrm{E}-01$ & & Complete result \\
\hline \multirow{7}{*}{10} & 0 & $5.57 \mathrm{E}+00$ & $1.59 \mathrm{E}+00$ & Complete result \\
\hline & 1 & $6.97 \mathrm{E}-05$ & 7.76E-05 & None \\
\hline & 3 & $2.92 \mathrm{E}-04$ & $2.22 \mathrm{E}-04$ & None \\
\hline & 6 & $8.55 \mathrm{E}-04$ & $9.15 \mathrm{E}-04$ & None \\
\hline & 9 & $3.69 \mathrm{E}-04$ & 4.89E-04 & None \\
\hline & 24 & $1.22 \mathrm{E}-02$ & $1.09 \mathrm{E}-02$ & None \\
\hline & Positive control & $7.02 \mathrm{E}+00$ & & Complete result \\
\hline \multirow{7}{*}{100} & 0 & $4.52 \mathrm{E}+00$ & 2.57E-01 & Complete result \\
\hline & 1 & $5.16 \mathrm{E}+00$ & 5.43E-01 & Complete result \\
\hline & 3 & $1.93 \mathrm{E}-03$ & $1.43 \mathrm{E}-03$ & Complete result \\
\hline & 6 & $5.94 \mathrm{E}-04$ & 4.19E-04 & Complete result \\
\hline & 9 & $4.69 \mathrm{E}-03$ & $4.26 \mathrm{E}-03$ & Complete result \\
\hline & 24 & $1.79 \mathrm{E}-03$ & $1.90 \mathrm{E}-03$ & Complete result \\
\hline & Positive control & $3.33 \mathrm{E}+00$ & & Complete result \\
\hline
\end{tabular}

Table 2: DNA quantification and amplification results for cells transfer with a weight of $200 \mathrm{gm}$.

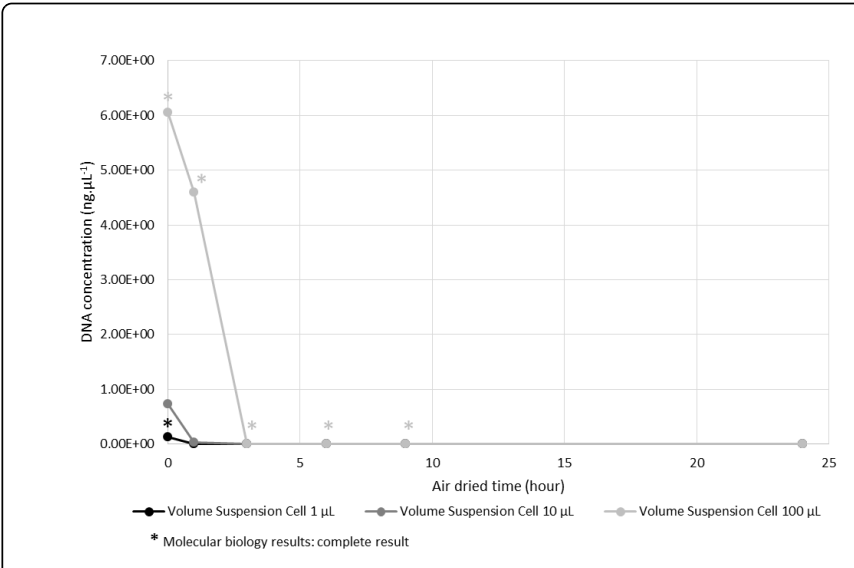

Figure 1: DNA quantification and amplification results for cells transfer with a weight of $20 \mathrm{gm}$.

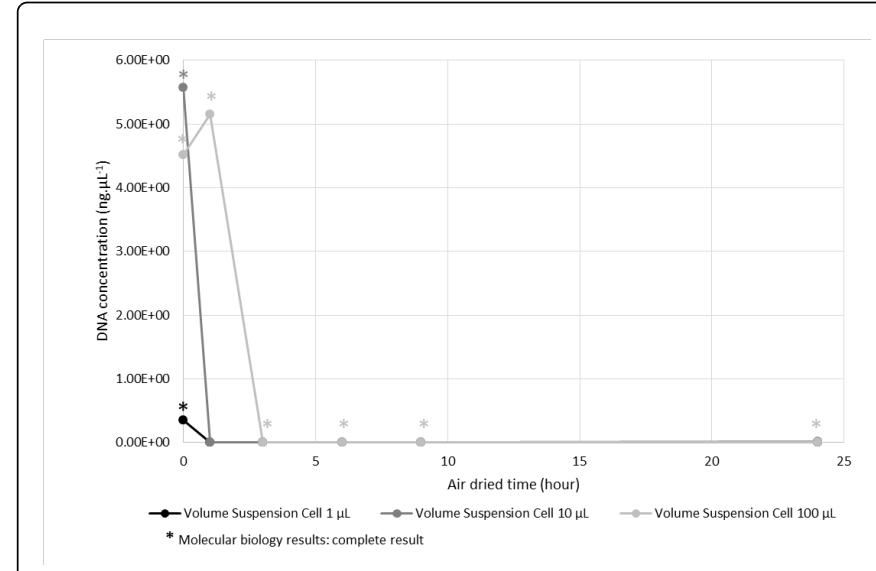

Figure 2: DNA quantification and amplification results for cells transfer with a weight of $200 \mathrm{gm}$. 
Citation: Piters A, Esponda A, Monique G, Doutremepuich A, Fromentin S, et al. (2017) Epithelial Cells Transfer: An Experimental Study. J

Page 4 of 4

\section{Conclusion}

Using this experimental model, we showed that secondary transfer can only occur when the epithelial cells are not strongly attached to their support, that is, approximately in the hour following cell deposition. Indeed, we observed that after this period, cells transfer is no longer possible because of the strong adhesion of the cells on their support that make them difficult to detach [5].

Our experiments also demonstrated that the environment conditions and parameters such as hygrometry and temperature play an important role in the drying of the cells but they also revealed that if a contact is necessary for cells transfer, the transfer occurs independently of the weight applied during this contact.

These analyses are very important to interpret the results of the DNA profiles obtained and to contextualize them. Frequently, in
Court, secondary transfer is used as an excuse to justify the presence of epithelial cells on an object when actually, this secondary transfer can't occur.

\section{References}

1. Cale CM (2015) Forensic DNA evidence is not infallible. Nature 526: 611.

2. Doutremepuich C (2012) Genetic fingerprints in court practice. Bull Acad Natle Med 196: 1117-1130.

3. Piters A, Esponda A, Beaufils M, Guillaume M, Doutremepuich A, et al. (2016) Persistence of stains and DNA on evidence in hostile situations. Peertechz Journal of Forensic Science and Technology 2: 010-012.

4. Butler JM (2011) Advanced Topics in forensic DNA typing. Methodology edited by Elsevier Academic Press, USA.

5. Samie L, Hicks T, Castella V, Taroni F (2016) Stabbing simulations and DNA transfer. Forensic Sci Int Genet Suppl Ser 22: 73-80. 